\title{
Філософія та література: шлях до діалогу
}

\section{Салій А. В., Українська медична стоматологічна академія}

Основна увага у матеріалі звертається на сфери взаємовпливів між філософією та художньою літературою. Вказується на те, що можливості взаємодії між цими течіями диктуються не лише культурними орієнтирами, але і соціально-історичними передумовами.

Акцентується увага на тому, що філософські пошуки були напрямком притаманним для більшості визначних письменників XIX століття, а це, у свою чергу, особливо важливо на тлі значної віддаленості філософії від літератури у цей період.

На прикладі російської літературної традиції XIX - XX століть автор наочно демонструє тісне співвіднесення філософської поезії та прози саме через суспільно значущу проблематику,проводячи прямі паралелі між поетичними творами О.Пушкіна, М.Лєрмонтова та психологічними романами Ф.Достоєвського і Л.Толстого. Хоча схожі тенденції притаманні і французькій, і німецькій та іншим літературним традиціям зазначеного періоду.

Автор намагається довести, що література може бути джерелом філософствування, але при цьому філософія осмислює літературу. Це призводить до формування особливих дисциплінарних утворень, які мають здатність якісно переосмислювати і перебудовувати саму практику писання і практику філософствування. Але одночасно ми розуміємо і приймаємо той факт, що сучасність не надає нам підстав виводити який-небудь спільний знаменник під літературою і філософією. Адже існують такі літературні практики, які будуть дуже близькими до філософії і неначе з нею зживатимуться, але існує і величезна кількість філософських практик, які будуть так само близькими до літератури. У статті доводиться, що взаємодія філософії та художньої літератури відбувається в усі історичні періоди, змінюються тільки формат та механізми такої взаємодії.

Ключові слова: історія філософії; текст; культурна асиміляція; філософський дискурс; літературний дискурс; діалог

\section{Philosophy and Literature: the wey towards the dialogue}

\section{Salii A. V., Ukrainian Medical Stomatological Academy}

The author analyzes the relebans issue of interaction between philosophical and literary discourses. The main attention in the material focuses on the spheres of mutual influence between philosophy and artistic literature. It has been indicated that the possibilities of interaction are dictated not only by cultural landmarks, but also by sociohistorical preconditions.

The attention is focused on the fact that philosophical search was a direction inherent to most of the prominent writers of the nineteenth century, and this, in its turn, is especially important against the background of a considerable distance of philosophy from literature in this period.

By the example of the literary tradition in the nineteenth and twentieth centuries, the author clearly demonstrates the close correlation of philosophical poetry and prose exactly through the socially significant issues, by direct parallels between poetic works by O. Pushkin, M. Lermontov and psychological novels by F. Dostoevsky and L. Tolstoy. Although similar trends are typical of French, German and other literary traditions of the specified period.

The author tries to prove that literature can be a source of philosophizing, but at the same time philosophy comprehends literature. This leads to the formation of special disciplinary formations that have the ability to rethink and redefine the very practice of writing and practice of philosophizing. But at the same time, we understand that modernity does not give us reason to deduce a common denominator under literature and philosophy. After all, there are such literary practices that are very close to philosophy, as if being assimilated with it, but there is also a large number of philosophical practices that are as close to literature as possible. The author proves that the interaction of philosophy and fiction occurs in all historical periods, and only the format and mechanisms of such interaction change.

Keywords: history of philosophy; text; cultural assimilation; philosophical discourse; literary discourse; dialogue 


\section{Философия и литература: путь к диалогу}

\section{Салий А. В., Украинская медицинская стоматологическая академия}

Основное внимание в статье обращается на сферы взаимовлияния между философией и художественной литературой. Указывается на то, что возможности взаимодействия между этими направлениями диктуют не только культурная ориентация, но и социально-исторические предпосылки.

Автор доказывает, что литература может выступать в качестве источника философствования, но при этом практически всегда философия осмысляет литературу. В конечном итоге это приводит к формированию особых дисциплинарных образований, которые имеют способность качественно переосмыслить и перестроить саму практику писания и практику философствования в этом направлении. Однако одновременно, мы принимаем тот факт, что современное состояние культуры не дает нам оснований выводить какой-либо общий знаменатель под литературой и философией. Ведь существуют такие литературные практики, которые будут находиться всегда максимально близко возле философии и как будто с нею сроднятся. Но, одновременно, существует не меньшее количество философских практик, которые будут очень близко находится возле литературы.

В статье автор показывает, что взаимодействие таких мощных культурных сфер как литература и философия имеет место во все исторические периоды, изменятся может только формат и механизм такого взаимодействия.

Ключевые слова: история философии; текст; культурная ассимиляция; философский дискурс; литературный дискурс; диалог

\section{Постановка проблеми.}

$\mathrm{T}$ Тема взаємодії філософії та літератури ніяк не може бути названа новою. 3 різною інтенсивністю цікавість до неї з'являється у різні історичні періоди, але по-справжньому нового звучання вона набуває у XX столітті. Саме у цей час в Європі інтелектуали, на кшталт Ж. Дерріда, черговий раз починають пророкувати кінець філософії, а Р. Барт та Ж. Батай оголошують кінець літератури. На наш погляд, це природне явище і таке песимістичне налаштування у різний час притаманне будь-якій сфері інтелектуальної діяльності. Тим паче, що з іншого боку мова йде про переформатування ключових позицій та установок. А тому у деяких аспектах, поєднуючись із філософією, література повторює її досвід протистояння сама собі [3, с. 61].

Власне, зближення літератури і філософії відбувається у моменти розуміння історичних і соціальних контекстів, які можуть бути пов'язані iз соціальними катаклізмами. Як приклад можна навести тих самих сюрреалістів, які зверталися до психоаналізу - маємо I світову війну, дискусії про бідність поезії та ширення практик arte povera - II світова війна. Це багато у чому знакове міжвоєнне двадцятиліття, 1920 - 1930-ті роки, на перше місце виводять саме філософів і літераторів, які вчилися і вчили дивитися і вперед, і назад [5, с.14], мріяли про майбутне та розуміли, що без минулого воно неможливе.

Метою публікації ми визначаємо характеристику основних принципів взаємодії філософії та літератури, а також визначення перспективних на- прямків їх подальшої взаємодії.

\section{Виклад основного матеріалу.}

Гуманітарні науки в усій своїй повноті не можуть існувати ізольовано одна від одної у зв'язку з тим, що мислення людини і ії поведінка розвиваються згідно одних і тих самих законів, а отже література не просто сприймає і по-своєму відображає фундаментальні проблеми філософії. Художній твір у такому контексті сприймається як сфера для пошуку відповідей на ключові філософські питання [4, с. 337-338]. У такому ракурсі література містить у собі відображення як соціально-культурної, так і економічної та інших картин світу у певний проміжок часу. Тому літературний твір чи філософський текст не можуть бути сконцентрованою тільки на собі реальністю, вони тісно пов'язані зі своїм автором $[6$, с. 8$]$, 3 його життям, переживаннями, радостями.

Аналіз проблемного поля взаємовідносин i взаємовпливів філософії та художньої літератури входить до категорії найактуальніших питань сучасного інтелектуального життя. Особливо враховуючи те, що саме поняття «інтелектуального життя» обов'язково передбачатиме наявну полідисциплінарність і неабияке прагнення подолати раціональність наукового способу мислення. Більшість дослідників сучасності на вирішення проблеми взаємодії і взаємовпливу літератури і філософії дивляться оптимістично, вважаючи, що такі дві потужні сфери діяльності обов'язково повинні співіснувати [напр. 1, с. 91-92].

Хоча існує і протилежна позиція, прихильники якої переконані, що ототожнення філософсько- 
го знання і літературної творчості може привести до функціонального глухого кута. А Ю. Габермас взагалі писав про те, що хибна асиміляція однієї сфери діяльності іншою може призвести до ситуації, коли вони обидві ризикують втратити свою субстанціональність [10, с. 194]. Хоча, на наше переконання, коли мова ведеться не про асиміляційні процеси, а про обмін ідеями та методиками, то ризики заповнення художньою проблематикою філософських площин взагалі мінімальні. Ні література, ні філософія у такому випадку не втрачають своєї самобутності та унікальності.

В будь-якому разі нам необхідно враховувати те, що існує професійний літератор, існує професійний філософ і вони можуть визначатися, в першу чергу, інституціонально: літератори легітимізуються іншими літераторами, філософи - іншими філософами. Цей самий стан можемо визначити і по-іншому: професійний літератор - той, хто знає або ж хоча б має уявлення про те, що і коли відбувається у сфері літератури, і використовує це у своїй практиці, а професійним філософом буде так само той, хто усвідомлює і співвідносить себе із загальним контекстом світової філософської думки. При цьому філософ може досить вільно звертатися до літературної проблематики, а письменник так само вільно почувається у філософському середовищі. I їм для цього немає ніякої потреби проходити додатковий літературний чи філософський курс відповідно. Письменник може вільно почуватися поза філософською традицією, вільно використовувати праці М. Бубера, наприклад, і при цьому ніколи не тримати у руках ні Канта, ні Гегеля. I філософ так само може звертатись до романів Ф. Достоєвського чи М. Гоголя, знаходити у них щось важливе для власних конструкцій, але при цьому йому не потрібно досконало вивчати і знати усю історію літератури XIX століття.

Література як така ніколи не прагнула ні до якого знання, на відміну від філософії. Це при тому, що філософія, як будь-яка сфера культурного виробництва, спрямована на нові смисли і конструктивний опис тих смислів, які вже існують. У даному контексті можна згадати твердження С. Л. Франка, який вважав, що найглибші і найзначущіші ідеї проголошувалися не у систематичних наукових працях, а в зовсім інших формах - літературних [9, с. 474].

Важливим компонентом діалогу філософії i літератури буде існування спільного для них дискурсу мови і тексту. У літературному процесі ос- мислення мови починається тоді, коли існує намагання його якось видозмінити. А такі дослідження обов'язково будуть включати у себе порівняльний аналіз різноманітних висловлювань, які традиційно можуть розглядатися як філософські, з іншими типами мовлення - як то художнє або ж наукове. Філософія завжди перебувала у ситуації находження перед істиною і одночасного іiї пошуку. Тільки 3 часом змінюється ставлення філософії до мови. I якщо класична філософія розглядала мову як найнадійніший засіб, який би транслював істину, то сьогодні, за висловом Т. Адорно, філософський інтерес зміщується у бік вияву неконцептуального в контексті, репрезентації «повного не редукованого досвіду в серцевині концептуального міркування» $[11$, p. 13]. Це може означати втрату філософським дискурсом тих властивостей, які зближали його із чистою наукою та набуття якостей художньо побудованої мови, до якої не застосовується процедура верифікації. I тому цілком природнім буде те, що взаємодія філософського і літературного дискурсу видаватиметься цікавою і актуальною.

Така актуальність буде тим більше закономірною, якщо ми розглядатимемо цю проблему у світлі яскравих соціально-культурних процесів XIX-XX століть, які можуть тлумачитися як дискурс на зближення філософії і літератури, а можливо і як взаємодія стійких і достатньо самостійних елементів. В будь-якому разі, коли мова ведеться про контекст поєднання, нам важливо чітко визначатися, що саме ми поєднуємо і що з цього нам достеменно відомо. Так, власне, ми можемо говорити про окремий прошарок мислителів, у яких художнє сприйняття життя і світу, діяльності людини зливаються воєдино із філософським баченням. Вони використовують літературно-художній жанр для обрамлення і популяризації власних філософських переконань. У Франції так робили Д. Дідро, А. Камю, Ж. П. Сартр; в Німеччині Ф. Ніцше, Г. Гессе, Т. Манн; в Росії - Ф. Достоєвський, Л. Толстой, А. Чехов; в Україні I. Франко, М. Коцюбинський, Л. Українка і т.д.

Так, у якості прикладу, в Російській імперії вимоги до філософської поезії та прози тісно співвідносилися із тією ж проблематикою, яка стояла загалом перед суспільством. Чітке спрямування на інтенсивність поетичного пізнання світу і людини, на поглиблений психологізм були цілком природніми для загальних тенденцій літературного розвитку [7, с. 9-10]. Через це сміливо можна стверджувати, що між філософською поезією та прозою першої половини XIX століття 
(О. Пушкін, М. Лєрмонтов) і психологічними творами Ф. Достоєвського чи Л. Толстого існує самий тісний зв'язок. Характерною рисою ХІХ століття $\epsilon$ i те, що філософські пошуки притаманні майже всім значущим письменникам. I це у той час, коли художня література знаходиться на найбільшій відстані від філософії.

Можна визнати, що наявний інструментарій дискурс-аналізу в умовах необхідної історичної контекстуалізації дозволяє, не заважаючи філософській герменевтиці, досліджувати певні специфічні умови, при яких який-небудь вислів створюється і сприймається у подальшому як філософський. Але, як зазначає А. Корчинський, поняття «дискурс» буде значно ширше, аніж поняття мови, тексту або стилю як відповідних характеристик вислову. Такий підхід, окрім усього іншого, дає можливість бачити те, що факт використання, наприклад, поезією філософських термінів або філософією образних характеристик, взаємні стилізації не знімають існуючих відмінностей між літературою і філософією на рівні дискурсу [8]. Навіть більше того, будь-які форми текстового і жанрового зближення філософії і літератури можуть бути можливі саме завдяки тому, що поки що у межах існуючого культурного поля заведено ці дискурси розрізняти.

На підтвердження такої думки можна навести результати аналізу праць Ж. Дерріда російською дослідницею Н. Автономовою, яка акцентує увагу на тому, що родзинка філософії не зникає через контакти з літературою та іншими дискурсами [2, с. 327]. Вона ж звертає увагу не лише на креативні аспекти інтелектуальних комунікацій, але і на особливості культурного простору, який буде передавати зміст філософського висновку.

Важливо не забувати, що проблема співвідношення і диференціації філософського дискурсу $з$ літературним буде значимою не тільки для визначеного нами XIX-XX століття. Філософія і література взаємодіють в усіх епохах, лише механізми і причини цієї взаємодії будуть різними. Саме в призмі контактів, а не ізоляції може проявитися дискурсивна особливість літератури i філософії. Звичайно, що у XIX-XX століттях їх взаємодія і взаємовпливи можуть заходити до таких меж, що може постати питання «розмивання кордонів» між ними. Хоча зауважимо, що кордони між філософським мисленням і художнім - це поняття неоднозначне. I тому часто дослідники можуть говорити не стільки про кордони як такі, як про розриви між філософією та літературою. Але сама поява такої проблеми не може сприйматися як певний симптом майбутнього дискурсивного синтезу. Все проблемне поле може пояснюватися логікою свого часу.

\section{Висновки.}

Отже, підсумовуючи сказане, ми можемо говорити про те, що зближення філософії та літератури можливе і необхідне для розуміння тих стрімких світоглядних змін і перетворень, які відбуваються у площині сучасної культури. У цьому контексті потрібне певне їх філософсько-літературне відображення, яке дозволить деякою мірою переосмислити і самі явища філософії та художньої літератури.

Вкрай важливо і те, що філософія та література перетинаються змістовно у сфері вирішення метафізичної проблематики. Тому література не тільки відчуває на собі вплив філософських ідей свого часу у більш ширшому розумінні, вона сама приймає участь у їх формуванні. Виходячи 3 цих позицій, література виступає як своєрідний випробувальний майданчик для філософії, одночасно сприяючи виникненню нових концепцій та нових шляхів філософування.

Художня література та філософія не просто взаємодоповнюють один-одного, вони взаємозбагачуються і значно розширюють власний внутрішній потенціал. Тому і діалог між ними неминучий, адже художня література дає філософії потужний матеріал для глибокого розуміння сутності життя взагалі, для кращого розуміння напрямків суспільного розвитку, подолання сухого раціоналізму, який час від часу відриває людину від чуттєвої сфери пізнання. Можна говорити про те, що саме література допомагає філософам сформувати цілісну картину світу. Тому шлях подолає той, хто йде...

\section{БІБІЛІОГРАФІЧНІ ПОСИЛАННЯ}

1. Автономова Н. Г. Философия и филология (о российских дискуссиях 90-х) / Н. Г. Автономова // Логос. - 2001. - № 4. - С. 91-105.

2. Автономова Н. Г. Философский язык Жака Деррида / Н. Г. Автономова. - М.: РОССПЭН, 2011. - 510 с.

3. Ажимов Ф. Е. Метафизические проблемы взаимоотношения философии и литературы / Ф. Е. Ажимов // Гуманитарные исследования в Восточной Сибири и на Дальнем Востоке. - 2010. - № 3. - С. 56-62

4. Гольдман Л. Структурно-генетический метод в истории литературы / Л. Гольдман // Зарубежная естетика и теория литературы ХІХ - ХХ вв. - М.: издательство МГУ, 1987. - С. 335-348 
5. Єрмоленко В. Оповідач і філософ Вальтер Беньямін і його час / В. Єрмоленко. - Київ: Критика, 2011. - 280 с.

6. Ермоленко В. Далекі близькі. Есеї з філософії та літератури / В. Єрмоленко. - Львів: Видавництво Старого Лева, 2015. - 300 с.

7. Колесников А. С. Философия и литература: современный дискурс / А. С. Колесников // Серия «Мымлители». История философии, культура и мировоззрение. - СПб.: Санкт-Петербургское философское общество, 2000. - № 3. - С. 8-36

8. Корчинский А. В. Форманты мысли: литература и философский дискурс / А. В. Корчинский. - М.: Языки славянской культуры, 2015. - 288 с.

9. Франк С. Л. Духовные основы общества / С. Л. Франк. - М.: Республика, 1992. - 511 с.

10. Хабермас Ю. Философский дискурс о модерне / Ю. Хабермас. - М.: Весь мир, 2003. - 416 с.

11. Adorno T. Negative dialectics / T. Adorno. - London and New York: Routledge, 1973. - 416 p.

\section{REFERENCES}

1. Avtonomova, N.G. (2001). Filosofiya i filologiya (o rossiyskich diskussiyach 90-h) [Philosophy and philology (about Russian discussions 90-h)]. Logos, 4, 91-105 [in Russian].

2. Avtonomova, N.G. (2011). Filisofskiy yazyk Zhaka Derrida [Philosophical language of Jacques Derrida]. Moscow: ROSSPEN [in Russian].

3. Azhymov, F.E. (2010). Metafizicheskie problemy vzaimootnoshenia filosofii I literatury [Metaphysical problems of the relationship between philosophy and literature]. Gumanitarnye issledovaniya v Vostochnoy Sibiri s na Dalnem Vostoke, 3, 56-62 [in Russian].

4. Gol'dman, L. (1987). Strukturno-geneticheskiy metod v istorii literatury [Structural-genetic method in the history of literature]. Moscow: MGU [in Russian].

5. Ermolenko, V. (2011). Opovidach i filosof Valter Beniamin i yogo chas [The narrator and philosopher Walter Benjamin and his time]. Kyiv: Krytyka [in Ukrainian].

6. Ermolenko, V. (2015). Daleki blyzki. Esse z filosofii ta literatury [Far close ones. Essays on Philosophy and Literature]. Lviv: Vydavnyztvo Starogo Leva [in Ukrainian].

7. Kolesnikov, A. (2000). Filosofiya i literatura: sovremennyi diskurs [Philosophy and Literature: modern discourse]. Seria Mysliteli. Istoria filosofi, kultura i mirovozzrenie [in Russian].

8. Korchynskiy, A.V. (2015). Formanty mysli: literatura i filosofskiy diskurs [Formants of thought: literature and philosophical discourse]. Moskow: Yazyki slovianskoy kultury [in Russian].

9. Frank, S. (1992). Duchovnye osnovy obszestva [Spiritual foundations of society]. Moskow: Respublika [in Russian].

10. Habermas, Y. (2003). Filosofskiy diskurs o moderne [Philosophical Discourse on Modernity]. Moscow: Wes' mir [in Russian].

11. Adorno, T. (1973). Negative dialectics. London and New York: Routledge.

\section{Салій Анатолій Володимирович}

Кандидат філософських наук, доцент

Українська медична стоматологічна академія

36000, Полтава, вул. Шевченка, 23

\section{Saliy Anatoliy}

$\mathrm{PhD}$ in Philosophy, Associate Professor

Ukrainian Medical Stomatological Academy

23, Shevchenko Str., Poltava, 36000, Ukraine

ORCID: 0000-0003-3761-0243Ｅmail: anatoli.salj@gmail.com

Цитування: Салій А. В. Філософія та література: шлях до діалогу / А. В. Салій // Науково-теоретичний альманах «Грані». - 2018. - Т. 21. - № 6. - С. 46-50.

Citation: Salii, A.V. (2018). Filosofiia ta literatura: shliakh do dialohu [Philosophy and Literature: the wey towards the dialogue]. Scientific and theoretical almanac «Grani», 21(6), 46-50. 